\title{
Arkansas Corporations Involve Employees In Programs Promoting Social Responsibility
}

Gayle Webb White, Southern Arkansas University, USA

\begin{abstract}
The area of social responsibility discussed in this paper is limited to that which would involve the employees of the company directly. Numerous ideas involving social programs aiding children and the local communities, social programs relating to the particular business of the companies, and social programs the company could become involved in that have a national network affiliation are discussed. Examples of companies that utilize their benefits program to further environmental or social issues are included. Further, the paper should prove valuable to university business professors as enhanced lecture material for classes. The research should prove valuable to company executives wanting ideas as to specific programs in which they can involve their employees that have proven to be successful at promoting environmental or social responsibility. The importance of the topic was verified by the 2007 Fortune Leadership issue which contained the results of a survey of approximately 550 companies around the world noted for developing leaders. These companies reported community involvement as one of the top three reasons potential employees gave for choosing a company, thus enhancing recruitment and retention. The study of Arkansas corporations revealed the state to be a leader in promoting social responsibility among employees.
\end{abstract}

Keywords: Community involvement, Corporate social responsibility, Smoking cessation programs, Environmental issues, Food pantries, Disaster relief,

\section{INTRODUCTION}

Tith many multinational corporations "talking up" their social responsibility, a recent international study by Bebbington, a professor at St. Andrews University stated that "fewer than four percent of the world's 50,000 major companies produce reports on corporate social responsibility" and she adds that the reports produced are "almost universally trivial" (Bebbington, 2006). Thus, a way for socially-minded companies to promote more social responsibility is to involve employees. The state within the United States that has taken the lead in promoting the belief that a company could be a vehicle for social change is Vermont; this idea has been a part of Vermont's business culture since the forties and the state attracts socially-minded employees (McCuan, 2004).

The reasons corporations are involving employees in programs emphasizing social responsibility are numerous. First, many employees have a need to help other people; this gives them their feeling of selfactualization, as referred to years ago by psychologist Abraham Maslow. Therefore, programs designed to allow employees to be involved in socially responsible programs can be motivating. Employees have had experiences in their lives that make certain charitable organizations very special to them; allowing them to work with these organizations can be very fulfilling. Also, with the hectic schedules that many employees lead filling their roles as spouse, breadwinner, parent, religious leader, good community person, etc., the time to become involved in a favorite socially responsible activity is limited. Further, many professors at AACSB accredited institutions have instituted breadth in business education through a service-learning component which, in turn, graduates more students who are socially responsible (Godfrey and others, 2005). 
In addition, citizens and environmental groups are beginning to judge a company based on the social behavior exhibited. For example, as Apple was launching its iPhone in June 2007, an environmental group called Climate Counts released a scorecard ranking major corporations on their tracking, reporting, and reduction of greenhouse gases. Apple was at a low of 2 out of 100 in the electronics industry. Estz stated that "those who fail to monitor, report and mitigate emissions face the prospect of mounting competitive disadvantage" (Estz, 2007).

Further, with the "black eye" that many corporations have as a result of scandals involving such things as executive misappropriation of funds, polluting of the environment, pirating of employee retirement funds, etc., executives are searching for ways to improve their corporate image. Fox maintains that marketing of social responsibility has accelerated tremendously since "terrorist attacks, corporate scandals and growing environmental concerns" (Fox, 2007). Involving employees in socially responsible programs in the communities where they operate can be one way to accomplish the goal of improving corporate image. This further seems to be a very appropriate time for companies to include corporate social responsibility as a corporate goal as a recent survey of M.B.A. students revealed that 81 percent of those responding believe businesses should work to improve society (Mangam, 2006). In fact the Fortune leadership issue confirmed the best young employees cite "job flexibility, development, and community involvement" as the top three factors in keeping them with a company (Colvin, 2007).

In addition to a review of the literature to determine programs currently in use by corporations that involve their employees in socially responsible programs, a questionnaire will be prepared and mailed to selected Arkansas corporations to determine how wide-spread social responsibility programs are in the state.

\section{INNOVATIVE EMPLOYEE SOCIAL PROGRAMS}

This section of the paper presents examples of successful programs that corporations have begun that involve their employees in environment-saving and socially responsible programs. It will also present programs the organizations have begun themselves in their effort to call attention to the need to protect the environment, improve the communities, and to give back to society.

Several of the Social Programs Aiding Children and the Community will be discussed below. Ariel, the Chicago firm which runs three mutual funds and has $\$ 17$ billion in assets under management, involves employees in educating African-American kids about investing. Its 97 employees reach out to the children of Chicago "through Ariel Community Academy, a public school that the firm helped the city found and that it supports" (Pofeldt, 2006). Each first-grade class receives \$20,000, which Ariel invests. Ariel president, Mellody Hobson, gives regular lectures at the school to both students and their parents on a variety of topics such as saving and investing. They report in very child-friendly statements which the students can understand. President Hobson says that "Ariel Community Academy allows us to attract like-minded employees who have a sense of community" (Pofeldt, 2006). Daily reported that many banks also believe that helping young children to learn to save and manage money is the right charity for them. Strategies include no minimum amount to deposit, no service charges, chances to receive gifts through drawings after depositing, etc. (Daily, 2007). Many of these banks have developed fun web sites that provide education while the students have fun.

Imagine Canada gave a twist to the traditional secret Santa parties that many companies host during the holidays and rather than bring a gift for an employee, they brought a gift to symbolize the recipient that would then go to a child. For example, someone who likes to cook might receive an Easy-Bake Oven; the toy would then be turned over to a local toy drive in the employee's name.

PETCO began to donate leftover prepared food to various food rescue programs after its large 2,500attendee annual conference (Dosh, 2007). Food rescue has become more popular with meeting planners; these planners determine which organizations will receive donations two weeks before the event. This assures it can be picked up in refrigerated trucks and delivered on the same day. It's a win-win situation because companies can receive a receipt which can be used for tax purposes and the Good Samaritan laws protect the donating companies from liability and the community where the event is held has added donations for their food program for the needy (Dosh, 2007). 
Fortessa, a Virginia based tableware company, sponsored their fourth annual Share Our Strength's Chefs on Bikes motorcycle ride. The 100-mile-plus ride "raised more than $\$ 50,000$ for Share Our Strength, the nation's leading organization working to end childhood hunger in America" (Nation's Restaurant News, 2007).

Children of service members who are recovering at Walter Reed Army Medical Center have a new playground thanks to a Yellow Ribbon Fund and the employees of BAE Systems who raised $\$ 60,000$ for the playground project (FDCH Regulatory Intelligence Database, 2007).

Microsoft Canada has merged celebrating achievements with social awareness - their annual family holiday party. The company rents blow-up playgrounds, hires clowns, brings pizza and presents for the children of the employees. However, not only do the children of the employees attend but for the fifth year running, the company will invite more than $\mathbf{4 0 0}$ children from the Boys and Girls Club selected by their partners in the organization. Dedicated employees volunteer to run the event (Warren, 2007).

Several social programs relating to the business of the company will be discussed below. Seventeen firms in New York City involved in engineering, construction, and architecture joined together to form ACE Mentor Program for Architecture, Construction, and Engineering. The program was launched in 1994 with 17 firms forming three teams who worked directly with about 90 students from local high schools throughout New York. These teams or mentors spent a total of 30 to 45 hours with participating students over a nine-month period. The program has now grown from three to 600 teams mentoring 30,000 students in 91 cities. Approximately 82 percent of participants are minorities. About 92 percent of students going through the ACE Mentoring Program enter college or an apprenticeship program after high-school graduation (Mullender, 2007).

The CEO of Patagonia, Inc., a leading apparel company, asks employees and customers to return wornout clothing which can then be made into new garments. Michael Crooke, Patagonia's CEO maintains that energy use could be cut about 75 percent along with carbon dioxide emissions by recycling, as compared with what it takes to make clothing from virgin materials (In Business Editorial, 2005).

One company, Meeting Strategies Worldwide, a conference management firm that specializes in "green" meeting strategies, has sold the idea to many corporations. Not only is leftover food donated but also bags, pens, pencils, foam core board that was used for signage, $t$-shirts - these can go to art centers organizations for children, community centers, or schools (Dosh, 2007). It would be important to let employees of the companies know; this could be done through brochures scattered around the conference. Thus employees of the companies could know that they gave back to the community and to people in need. Hooters based in Atlanta donated $\mathbf{\$ 2 5 0 , 0 0 0}$ to the Jimmy V. Foundation for Cancer Research to support breast cancer research in honor of Kelly Jo Dowd, one of the original Hooters waitresses at the company's first location in Clearwater, Florida (Nation's Restaurant News, 2007).

SELCO Community Credit Union has a unique program that involves their employees and the customers of the credit union in community social programs of all types. SELCO developed a "sort of match-making site for volunteers and non-profit organization" called Give With Us (Jepson, 2007). For example, when the Department of Human Services is looking for helpers to drive foster children to visit their parents, employees and community citizens interested can make the necessary contact to volunteer for this assignment. SELCO has been recognized as a leader when it comes to giving back to the community. The Give With Us Program is now available to any credit union.

Allen Lutes, president of Alpha Remodeling, "created a Labor of Love, a program designed to aid the elderly, disabled, and financially challenged to take care of their homes in the Ann Arbor area" (Sweet, 2007). The remodeling industry is often portrayed as criminals preying on unsuspecting homeowners because of the action of a few unscrupulous individuals. However, a number of those in the remodeling business spend a good portion of time giving back to their communities through such programs as Habitat for Humanity, Katrina Relief, and other natural disaster causes. 
Peter Piper Pizza, the 130 chain based in Scottsdale, Arizona, donated more than 1,600 pizzas to schools after more than 140,000 students and staff at Arizona schools raised nearly $\$ 160,000$ to support the Pennies for Patients program run by The Leukemia and Lymphoma Society. Fifth Group Restaurants based in Atlanta, Georgia, was a lead sponsor for Taste of the Highlands, which raised more than $\$ 26,000$ for Children's Health Care of Atlanta. Employees were involved in both of these projects (Charitable Chatter Column, Nation's Restaurant News, 2007).

Several social programs at the national level will be discussed below. One interesting program that was started at the corporate level and has grown to the national level is a program initiated by Patagonia. Yvon Chouinard founded the program by agreeing for his company to donate at least one percent of net revenues to efforts that protect and restore the natural environment. The program called "One Percent for the Planet" now has 574 (as of June 8, 2007) other partners donating one percent of net revenues to the effort (Bucaro, 2007).

Some company executives have tackled social problems such as health care costs rising an average of thirty percent each year, rising to such an extent that it is pricing many employees out of the health care market. For example, Jim Hagedorn of Scotts Miracle-Gro has instituted incentive programs to decrease obesity and eliminate smoking. His program is based on the harsh reality that our workforce apparently lacks the basic selfdiscipline to control caloric intake and exercise every week and to quit smoking (Business Week Cover Story, 2007). Numerous companies have adopted similar programs.

Several companies are giving corporate gifts that are environmentally sound. Therefore, when it comes to corporate gifts for the holiday season, it's about corporate social responsibility. Examples of such gifts include solar-powered back packs with internal renewable batteries or bamboo shirts which are 100 percent biodegradable and grown without pesticides or chemicals (Pratt, 2007). The recipients will not only appreciate the product itself but will become "brand ambassadors knowing the company that gave them the product also cares about our environment on a global level" (Pratt, 2007).

There are many ways that companies help employees make contributions to their favorite charities. For example, a new stored-value card company, Giving Tree LLC, gives 10 percent of the value of each of its cards to a charity of the cardholder's choice. At the time the cardholder activates the card on the Giving Tree Web site, a 1.5 million item listing of non-profit organizations allows a choice by the cardholder as to where the donation can be made. Bob's Discount Furniture established a foundation and routinely raises money with such events and golf tournaments. Recently, they raised $\mathbf{\$ 3 5 0 , 0 0 0}$ for the charitable foundation at a golf and dinner events with over 300 employees and community leaders attending which benefited The Children's Medical Center in Hartford, the Family and Children's Aid in Danbury, and the American Cancer Society.

Several social programs emphasized through the companies' benefits programs will be discussed below. Many companies are organizing employees to form car pools to help cut down on pollution and to save resources. As an example, to keep the environment free from emissions, Google runs free shuttles to pick up and drop off employees from Bay Area locations. In addition, if an employee wants to buy a hybrid car, the company will give the employee \$5,000 "toward that environmentally friendly end" (Lashinsky, 2007).

At Timberland, all staff can devote 40 hours per year of paid time off to volunteer, and now up to 30 employees can spend two to three weeks a year to help with disaster relief. Also, at CDW, an IT product and service provider, workers are encouraged to lend a hand: CDW sent 80 co-workers to help in the Katrina cleanup, and later 300 co-workers went back to spend several days helping rebuild (Levering and Moskowitz, 2007).

\section{SOCIAL PROGRAMS IN OTHER COUNTRIES}

Special social programs are not only in the United States but in other countries as well. Unilever's operation in Brazil provides a free community laundry in a Sao Paulo slum and recycles $\mathbf{1 7}$ tons of waste annually at a toothpaste factory. Unilever funds a floating hospital that offers free medical care in Bangladesh, a nation with just 20 doctors for every 10,000 people. In Ghana, Unilever teaches palm oil producers to reuse 
plant waste. The CEO of Unilever believes that is the only way to run this conglomerate; this is certainly counter to conventional wisdom (Engardio, Chappel, and others, 2007).

Liberty Life matches "rand for rand" every donation an employee makes that is approved by their employee committee. Such programs as "Making a Difference Food" program, "Let's Dream Campaign" and many others are supported by the employees and the company's matching donation. Employees of the company are totally on board with over six hundred employees involved in the making dreams a reality program (Finweek, 2007).

A recent UK Survey revealed that consumers' concerns about the environment had increased. Consumers now "absolutely expect companies to play a significant part in working with them to make it easier to do the right thing" (Vincent and Dinghite, 2007). Further, when 100 Danish fashion companies met in Copenhagen this year, the challenges of adopting socially responsible policies were addressed, including a possible eco-friendly section at next year's exhibition, and, possibly, corporate social responsibility courses taught in fashion schools (Groves, 2007). A company's social responsibility is the top influencer when creating consumer loyalty.

\section{COMPANIES ORGANIZED AROUND SOCIALLY RESPONSIBLE IDEAS}

Many people want to become employees of companies that are founded around socially responsible ideas. A recent survey of M.B.A. students revealed that seventy-nine percent said they would seek jobs that were socially responsible (Mangan, 2006). One company, Durable Plastic Design, began production in 2004 of lowmaintenance 100 percent recycled plastic lumber. Owners estimate the company will use 140,000 pounds of recycled plastic each month. (In Business Editorial, 2005).

Many companies that provide incentives for marketing departments of companies have been formed in recent years. These include Eco Incentives, Recycled Mania, Remarkable, and Eco-T. Many companies now purchase their promotional giveaways from companies such as these (Bhavna, 2007).

\section{RESULTS OF THE ARKANSAS STUDY}

Using the information gathered in the review of the literature on social responsibility programs in use in America's businesses, a questionnaire was mailed to 100 companies selected from the 2007-2008 edition of the Arkansas Business Directory. The companies responding included large manufacturing firms such as rifle manufacturers, cosmetic companies, and food companies; banks and financial institutions; and insurance companies. With a fourteen percent response rate, only one questionnaire was returned with none written across the face. At some level, Arkansas businesses seem to be supporting their employees in programs involving social responsibility activities.

Eighty-five percent of the responding companies participated in Habitat for Humanity, Katrina Relief, and other natural disaster causes. Fund raisers for research for cancer, heart disease, diabetes, multiple sclerosis, and other diseases received a $92.3 \%$ response rate. Fund raisers to aid children such as providing for school supply needs, for establishing and furnishing playgrounds, for assistance to boys and girls clubs, Christmas toys for needy, etc. was at $85 \%$.

Donations of leftover prepared food after conferences (in refrigerated trucks on same day) was reported by $30.7 \%$ of companies responding. Yellow ribbon events to aid veterans and veterans' families was reported by $15.3 \%$ of companies.

The questionnaire included a couple of questions regarding weight reduction and smoking cessation programs since many consider this to be socially responsible-- to aid employees in these areas. However, it may not be the altruistic factor but the cost factor that causes the programs to be implemented. Sixty-two percent of companies indicated they support employee incentive programs to help employees and their families stop smoking while fifty-four percent sponsor incentive programs to help employees and their families fight obesity. 
Fifteen percent of the companies responding to the survey contribute a percentage of the company's annual sales to selected favorite charities of employees. Thirty percent of the respondents pay employees for their time off from work to work with charities; also, thirty percent match employees' charitable cash contributions of some basis.

One interesting facet of the survey was that almost seventy percent of the companies use their company's area of expertise and filled in the blank with examples. These include:

- $\quad$ A dental insurance company provides oral health education programs for school children as well as dental care for the uninsured and low income individuals

- A large banking corporation presents community sponsored workshops and seminars to area schools covering such topics as how to get a loan, credit counseling, investments, how to save money, how to maintain a checking account, etc.

- $\quad$ Another bank reported a "Teach Children to Save" day at elementary schools

- A construction company works with Habitat for Humanity

- A nationally-known food company works with hunger relief organizations, food banks, and clearinghouses

- $\quad$ One furniture company reported donations of furniture to non-profit organizations

- $\quad$ One health supply company reported donations of personal hygiene products to homeless shelters and other homes for the indigent

These were not all of the examples but are given as indicative of the types of related expertise donations being given by Arkansas corporations.

Not a single respondent reported the giving of gifts to employees/customers that are environmentally sound. However, in answer to an item that asked companies to share any additional programs in which their company had involved their employees, many took time to write in additional programs. These included:

- $\quad$ Our employees volunteer at the Arkansas Mission of Mercy.

- $\quad$ Our company has a "Community Service Team" and provide a variety of services such as volunteer at animal shelters, renovate rooms at a women's shelter, partner at local elementary school for school supplies, etc.

- $\quad$ Our employees donate food to the local mission/homeless shelter.

- We paid our employees to travel to the Mississippi coast to clean up co-workers homes/lawns after Katrina. We also set up a Katrina relief fund for employees.

- $\quad$ We regularly provide grants to various Arkansas agencies including United Way.

- $\quad$ Our company sponsors a "Making Waves" program in which employees can donate time to any local community project and the company will donate funds to the project based on the number of employees participating.

- $\quad$ Our company encourages recycling and has a depository for used toner/ink cartridges at our warehouse facility. Various locations have recycling bins for aluminum cans, paper, and even glass that is sent to the local recycling center.

These are a few of the comments written in the space provided for additional program involvement and indicates that many Arkansas corporations are involving their employees in programs that promote social responsibility.

\section{CONCLUSIONS AND RECOMMENDATIONS}

When corporations involve their employees in programs that promote social responsibility, they are helping to raise awareness within the nation. Employees will begin to demand that more attention be given to these programs. Prospective employees will begin to look for such companies when they interview for employment. Much of the current research substantiates that by being good corporate citizens, companies can attract top talent, can engage employees, and raise productivity. When Genzyme moved into their green-certified Genzyme Center and productivity increased, they surveyed employees to ask what the employees believed accounted for the 
productivity increase. The employees reported their increased productivity was due to "their increased sense of pride about Genzyme's commitment to the environment made through the new building" (Fox, 2007).

In addition, talent-strapped companies have found that corporate social responsibility can be a draw and grab the attention of a certain type of highly skilled, highly motivated employee. Capgemini in the Netherlands needed 800 IT and management consultants and found that rather than giving the T-shirt or coffee mug for completing a survey and submitting an application, the company's funding of a week of housing and schooling for poor children in India through a foundation garnered a larger number of interested, qualified applicants (Fox, 2007).

Also, news articles that spotlight corporate environmental abuses will bring about change. For example, after Apple's iPhone was launched in June of 2007 and met with criticism concerning greenhouse gases by the environmental group Climate Counts (Esty, 2007), then Dell Computer issued several news releases concerning their plans to reduce their emissions. Dell executives emphasized that employees' computers would be turned off at night and during long periods of inactivity and, thereby, cut carbon dioxide emissions by 8,500 tons. Dell further announced plans to require the companies who manufacture the computers to report emissions (Hesseldahl, 2007). There seems to be a correlation between these two separate news articles concerning two well-known computer companies; the Apple criticism preceded the Dell changes by a few months. As more companies become aware of the impact on sales of negative publicity associated with environmental issues, more changes such as these at Dell will most likely be made.

In addition, when companies make obvious efforts to involve their employees in programs to help the community, environment, etc., they must be certain they follow through and eliminate waste and be socially and environmentally conscious themselves. For an example, consideration should be given to the products the company gives away as part of the promotional and direct campaigns. There are many companies specializing in this. For example, Eco Incentives offers a range of items with an ethical twist. "Examples include bags and pens made from natural materials, USB memory sticks encased in wood rather than plastic, biodegradable T-shirts, and computer keyboards and monitors fashioned from bamboo" (Bhavna, 2007). This is simply an example, but there would be numerous other ways companies can be socially and environmentally responsible.

Further, as more universities teach future managers to assume a socially responsible decision making style, this will impact the environment positively. Also, the recent survey of M.B.A. students that reported that 79 percent planned to seek jobs at companies with a reputation for acting socially responsible is a positive sign that companies will become more socially and environmentally responsible in the future in order to attract competent employees.

\section{REFERENCES}

1. Bebbington, Jan (2006). "Corporate Social Responsibility Reports a Danger to Sustainable Future, Ecologist, Volume 36, Number 8, 2 pages.

2. Bhavna, Misty, (2007). "Righteous Rewards," Marketing, 00253650, Haymarket Business Publications, Ltd., August 1, 2007, 3 pages.

3. Bucaro, Frank, (2007). "When What Matters Most is Not Your Bottom Line," American Salesman, Volume 52, Number 10, 00030902 , October, 2007.

4. Business Week Cover Story, (2007). "Get Healthy—or Else," Business Week, wwwbusiness week.com. February 26, 2007.

5. Colvin, Geoff, (2007). "Leader Machines," Fortune (Special Leadership Report), Volume 156, Number 7 , October 1, 2007, pp. 98-106.

6. Community Matters Editorial, Nation's Restaurant News, (2007). "Hooters Donates \$250,000 for Breast Cancer Research," Nation's Restaurant News, September, 10, 2007, www.nrn.com.

7. Daily, Linda (2007). "Making a Deposit on the Future," Community Banker, Volume 16, Number 10, October,. 2007, 15291332.

8. Dosh, Corrie (2007). "The Guide to Doing Good," Successful Meetings, Volume 56, Number 9, August 1, 2007, 5 pages.

9. Editorial, Nation's Restaurant News, (2007). “Chefs on Bikes Fundraiser Nets More than $\$ 50,000$ for Share our Strength," Nation's Restaurant News, September 10, 2007, 
10. Engardio, Pete, Capell, Kerry, and others (2007). “Beyond the Green Corporation,” Business Week, Special Report, January 29, 2007, Number 4019, 8 pages.

11. Estz, Daniel C. (2007). "What Stakeholders Demand," Harvard Business Review, Volume 85, Number 10, pp. 30-34.

12. FDCH Regulatory Intelligence Database, (2007). “Groups Team Up to Entertain Military Kids,” Agency Group 09, FDCH Regulatory Intelligence Database, October 15, 2007.

13. Finweek Editorial, (2007). “Employees' Hearts and Minds are In It," Finweek, An 26906646, September 13, 2007, p. 72.

14. Fox, Adrienne, (2007). "Corporate Social Responsibility Pays Off," HRMagazine, Volume 52, Number 8, 6 pages.

15. Godfrey, Paul C., Louise Illes and Gregory Berry, (2005). "Creating Breadth in Business Education Through Service-Learning," Academy of Management Learning and Education, Volume 4, Number 3, September 2005, 19 pages.

16. Hesseldahl, Ariek, (2007). "Dell Aims to Go Carbon Neutral," Business Week Only, 26886420, September 28, 2007, pp. 23-24.

17. In Business Editorial, (2005). “Green Company Profiles, In Business, 01902458, Volume 27, Number 6, November/December 2005, 8 pages.

18. Jepson, Kevin, (2007). "SELCO Helps Link Members with Groups Needing Volunteers," Credit Union Journal, Source Media, Inc., October 22, 2007, 1 page.

19. Lashinsky, Adam, (2007). "Search and Enjoy," Fortune, Volume 155, Number 1, January 22, 2007 , p. 72.

20. Levering, Robert and Milton Moskowitz, (2007). "In Good Company," Fortune, Volume 155, Number 1, January 22, 2007, p. 94.

21. Mangan, Katherine (2006). "Most MBA Students Believe Companies Should Help Improve Society, Survey Finds," Chronicle of Higher Education, Volume 53, Number 11, November.

22. McCuan, Jess (2004). “It's Not Easy Being Green,” Inc. ,01628968, Volume 28, Number 11, 10 pages.

23. Mullender, Pamela, (2007). "Mentoring High School Students Works," Contractor Magazine, Volume 83, Number 10, October, 2007, pp. 41-45.

24. Nation's Restaurant News, (2007), “Charitable Chatter," Nation's Restaurant News, www.nrn.com. September 10, 2007, 1 page.

25. Pofeldt, Elain (2006). "Better Bosses,” FSB: Fortune Small Business, 15473171. Volume 16, Number 8, 3 pages.

26. Pratt, Laura (2007). "The Art of Giving," Marketing Magazine, Volume 112, Number 18, special section, pp. 16-18.

27. Sweet, Jonathan (2007). “Giving Back,” Professional Remodeler, Volume 11, Number 10, pp. 22-26.

28. Vincent, Luke and Dinghite, Liana, (2007). "For the Good of Mankind," Brand Strategy, October, 2007. Centaur Communications.

29. Warren, Michelle, (2007). "Party With a Conscience," Marketing Magazine, Volume 112, Number 18, 11964650, September 24, 2007, 2 pages. 